\title{
Analisa dasar proses pengolah sampah plastik bekas menjadi bahan bakar alternatif dengan proses pirolisis
}

\author{
Nuryosuwito ${ }^{1)}$, Fatkur Rhohman ${ }^{2)}$ \\ 1), 2) Program Studi Teknik Mesin, Universitas Nusantara PGRI Kediri \\ E-mail: ${ }^{1)}$ suwito.unp@gmail.com, ${ }^{2)}$ fatkurrohman@unpkediri.ac.id
}

\begin{abstract}
Abstrak
Penelitian ini dilatarbelakangi oleh semakin banyaknya sampah plastik yang sulit terurai. Sampah plastik menjadi sebab munculnya berbagai permasalahan, seperti: sumber penyakit, pencemaran tanah, pencemaran air, dan jika dibakar menjadi pencemaran udara yang sangat berbahaya bagi yang menghirupnya. Belum adanya cara pengolahan sampah plastik yang tepat menjadi masalah yang serius kedepan. Upaya pemanfaatan kembali (reuse) hanya berguna untuk memperpanjang masa pakai, tetapi tidak mengurangi jumlah sampah yang ada. Tujuan dari penelitian ini secara umum adalah untuk menyelesaikan permasalahan dari sampah plastik dengan cara merubah sampah menjadi bahan bakar alternatif pengganti bensin. Sedangkan secara khusus, tujuan penelitian ini adalah untuk mengambil data yang dihasilkan dari proses pirolisis, meliputi data suhu api kompor, suhu tungku, suhu dalam tungku, suhu pendingin, jumlah cairan yang dihasilkan dari hasil proses pirolisis tersebut, dan residu yang dihasilkan dari proses pirolisis tersebut. Sehingga dapat diperoleh menurunan bobot dari sampah awal dengan sampah akhir. Gambaran proses untuk merubah sampah plastik menjadi bahan bakar alternatif tersebut adalah dengan dilakukan pembakaran sampah agar menjadi bentuk cair dalam alat pirolisis. Dari penelitian ini, diperoleh beberapa data yang diperoleh dari hasil proses pirolisis tersebut. Dari data yang telah diketahui, untuk suhu api, suhu luar tungku, dan suhu dalam tungku, dan jumlah BBM hasil pirolisis senderung meningkat, sampai pada suatu waktu cenderung stabil. Hal itu menandakan bahwa proses telah selesai karena sampah sudah tidak bisa diolah menjadi bahan bakar cair lagi. Sedangkan untuk suhu ruang pendingin, terjadi kenaikan dan penurunan yang tidak stabil. Sehingga tidak bisa digambarkan dengan baik.
\end{abstract}

Kata Kunci: bahan bakar alternatif, kandungan hasil pengolahan, pirolisis, sampah plastik.

Abstract

This research is motivated by the increasing number of plastic waste that is difficult to decompose. Plastic waste is the cause of various problems, such as: sources of disease, soil pollution, water pollution, and if burned into air pollution which is very dangerous for those who breathe it. The lack of proper processing of plastic waste is a serious problem going forward. Reuse is only useful for extending the life span, but does not reduce the amount of waste available. The purpose of this study in general is to solve the problems of plastic waste by turning waste into alternative fuels instead of gasoline. Whereas specifically, the purpose of this study is to retrieve data generated from the pyrolysis process, including data on stove fire temperature, furnace temperature, furnace temperature, coolant temperature, amount of liquid produced from the results of the pyrolysis process, and residues generated from the pyrolysis process that is. so that it can be obtained decreasing the weight of the initial garbage with the final waste. 
The description of the process for converting plastic waste into alternative fuels is by burning garbage to become a liquid form in the pyrolysis tool. From this study, obtained some data obtained from the results of the pyrolysis process. From the data that has been known, for the temperature of the fire, the temperature of the furnace, and the temperature in the furnace, and the amount of fuel produced by the pyrolysis of the joint increases, until at one time it tends to be stable. This indicates that the process has been completed because garbage cannot be processed into liquid fuel anymore. As for the temperature of the cold room, there is an unstable increase and decrease. So that it cannot be described properly.

Keywords: alternative fuels, plastic waste, pyrolysis, results processing.

\section{PENDAHULUAN}

Masalah sampah semakin hari menjadi semakin rumit. Dengan semakin banyaknya jumlah sampah yang dihasilkan setiap hari, maka itu berarti semakin banyak juga titik masalah yang dihasilkan. Pada tahun 2015, jumlah sampah di Indonesia perhari mencapai 64 juta ton, sedangkan pada tahun 2016, jumlah sampah tersebut meningkat menjadi 65 juta ton perhari [1]. Masalah dari sampah secara umum dapat dituliskan sebagai berikut [2]:

a. Menurunnya nilai estetika lingkungan, lingkungan menjadi kotor dan jorok

b. Pencemaran udara oleh gas-gas yang ditimbulkan, seperti gas metan atau $\mathrm{CO}_{2}$ hasil dari pembakaran

c. Pencemaran tanah dari bahan berbahaya dan beracun yang tercampur dalam sampah

d. Pencemaran air dari bahan berbahaya dan beracun yang merembes masuk ke dalam air tanah atau air permukaan disekitarnya

e. Kerumitan sistem pengelolaan kebersihan karena melibatkan banyak orang dan banyak biaya yang mendorong terjadinya korupsi, kolusi, dan nepotisme

f. Membebani masyarakat dengan adanya kewajiban membayariuran kebersihan mulai dari tingkat kampung hingga tingkat kota

g. Terganggunya kesehatan masyarakat dengan semakin jeleknya sanitasi lingkungan.

Dalam kamus istilah lingkungan, sampah adalah bahan yang tidak mempunyai nilai dalam pembuatan manufaktur atau materi berkelebihan yang ditolak. Menurut ecolink, sampah adalah suatu bahan yang terbuang atau dibuang dari sumber hasil aktivitas manusia maupun proses alam yang belum memiliki nilai ekonomis. Sedangkan menurut Dr. Tandjung, sampah adalah sesuatu yang tidak berguna lagi, 
dibuang oleh pemiliknya atau pemakai semula [3]. Sampah jenis plastik akan terurai dengan baik di alam selama kurun waktu 20 hingga 80 tahun, bergantung dari jenis sampah yang terbuang [4]. Sehingga semakin lama, sampah-sampah plastik tersebut akan semakin menumpuk secara tidak terkendali.

Sampai saat ini, pemerintah masih giat menggalakkan program 3R meliputi reduce, reuse, dan recycle. Bahkan saat ini ditambah dengan replant untuk mengatasi masalah sampah organik [2].

a. Reduce (Menghemat pemakaian)

Salah satu langkah yang bisa digunakan dalam kegiatan reduce ini adalah mengurangi penggunaan pembungkus. Hal ini bisa dilakukan dengan membeli makanan yang tidak berkemasan plastik, ataupun mengganti bungkus belanja dari tas kresek dengan tas daur ulang, kertas, atau bahan-bahan lain yang ramah lingkungan

b. Reuse (Pemakaian kembali)

Beberapa upaya yang dapat digunakan dalam kegiatan ini yaitu memperpanjang umur pemakaian dan mengembangkan manfaat lain.

c. Recycle (Mendaur ulang)

baBnyak hal yang bisa dilakukan dari mendaur ulang, antara lain Mendaur ulang plastik, mendaur ulang kertas, mendaur ulang sampah organik menjadi kompos, dan lain-lain. Mendaur ulang sampah untuk dijadikan kompos ada 3 cara yaitu membuat kompos dengan aktivator EM4, pengomposan secara sederhana di dalam area pengomposan, dan pengomposan menggunakan komposter.

d. Replant (Menanam kembali)

Replant merupakan salah satu upaya untuk menjadikan pekarangan rumah atau lahan yang kosong menjadi hijau.

Partisipasi masyarakat untuk berperan aktif menjadi suatu hal yang sangat penting dalam mengelola sampah. Pengolahan sampah tersebut dapat dimulai dari rumah tangga dengan cara pemilahan sampah organik, sampah anorganik maupun sampah B3. Dari pemilahan tersebut bisa diperlakukan dengan skema 3R plus, sehingga nantinya yang terangkut ke TPA hanya sisanya saja[5]. 


\section{METODE PENELITIAN}

Metode yang digunakan adalah pengamatan langsung dari proses penelitian. Proses penelitian menggunakan bahan dasar sampah plastik campur dalam kondisi yang tanpa perlakuan awal, seperti pemilahan jenis plastik maupun pengetingan. Sehingga diperoleh kondisi awal seperti yang ada di lapangan.proses pembakaran menggunakan alat pirolisis yang telah dimiliki oleh di laboratorium teknik mesin Universitas Nusantara PGRI Kediri. Dari hasil data tersebut, akan dipaparkan menggunakan statistik deskriptif. Namun sebelum dilakukan pemaparan menggunakan statistik deskriptif, penggambaran data akan dilakukan pengolahan dengan menggunakan diagram batang atau garis. Dalam penelitian ini, akan mengamati perubahan data dari waktu ke waktu.

\section{HASIL DAN PEMBAHASAN}

Dalam penelitian ini, pengambilan data dilakukan sebanyak tiga (3) kali. Adapun rata-rata data hasil penelitian adalah sebagai berikut:

tabel 1. hasil pengolahan sampah bekas dengan proses pirolisis

\begin{tabular}{|c|c|c|c|c|c|c|c|c|c|c|}
\hline No & Waktu & $\begin{array}{c}\text { Suhu } \\
\text { Kompor }\end{array}$ & $\begin{array}{c}\text { Suhu } \\
\text { Dalam }\end{array}$ & $\begin{array}{c}\text { Suhu } \\
\text { luar } \\
\text { tungku } \\
\text { kanan }\end{array}$ & $\begin{array}{c}\text { Suhu } \\
\text { luar } \\
\text { tungku } \\
\text { kiri }\end{array}$ & $\begin{array}{c}\text { Suhu } \\
\text { luar sisi } \\
\text { pintu }\end{array}$ & $\begin{array}{c}\text { Suhu } \\
\text { ruang } \\
\text { pendingin } \\
1\end{array}$ & $\begin{array}{c}\text { Suhu } \\
\text { ruang } \\
\text { pendingin } \\
2\end{array}$ & $\begin{array}{c}\text { Suhu } \\
\text { ruang } \\
\text { pendingi } \\
\text { n } 3\end{array}$ & volume \\
\hline 1 & 13.06 & 82,47 & 0 & 28,57 & 32,3 & 25,67 & 21,73 & 17,07 & 14,97 & 0 \\
\hline 2 & 13.31 & 201,8 & 70 & 105,27 & 112,53 & 102,03 & 2,07 & 0,27 & 1,37 & 65 \\
\hline 3 & 14.14 & 305,5 & 68 & 112,33 & 118,47 & 104,23 & 24,53 & 24,43 & 24,47 & 1050 \\
\hline 4 & 15.02 & 365,17 & 93 & 133,53 & 142,6 & 106,6 & 9,7 & 7,77 & 9 & 1900 \\
\hline 5 & 15.40 & 383,2 & 107 & 152,53 & 150,47 & 117,97 & 19,67 & 18,97 & 19,17 & 2270 \\
\hline 6 & 16.20 & 344,6 & 105 & 150,77 & 146,77 & 118,93 & 25,37 & 24,6 & 24,57 & 2565 \\
\hline 7 & 16.58 & 351,83 & 100 & 150,53 & 149,77 & 115,57 & 14,2 & 13,13 & 13,93 & 2730 \\
\hline 8 & 17,25 & 327,9 & 95 & 137,9 & 140,13 & 111 & 17,63 & 17,03 & 17,2 & 2760 \\
\hline
\end{tabular}

Dari data tersebut, maka dapat dibuat grafik untuk memudahkan dalam melihat tren peningkatan atau penurunan dari suatu kejadian. Ada 6 grafik yang bisa dilihat, yaitu:

a. Grafik peningkatan suhu kompor

Dari grafik peningkatan suhu kompor tersebut, diperoleh gambaran data yang meningkat pada awal pembakaran. Namun setelah mencapai suhu $383,2^{\circ} \mathrm{C}$, suhu cenderung stabil dengan gerakan relatif menurun. 


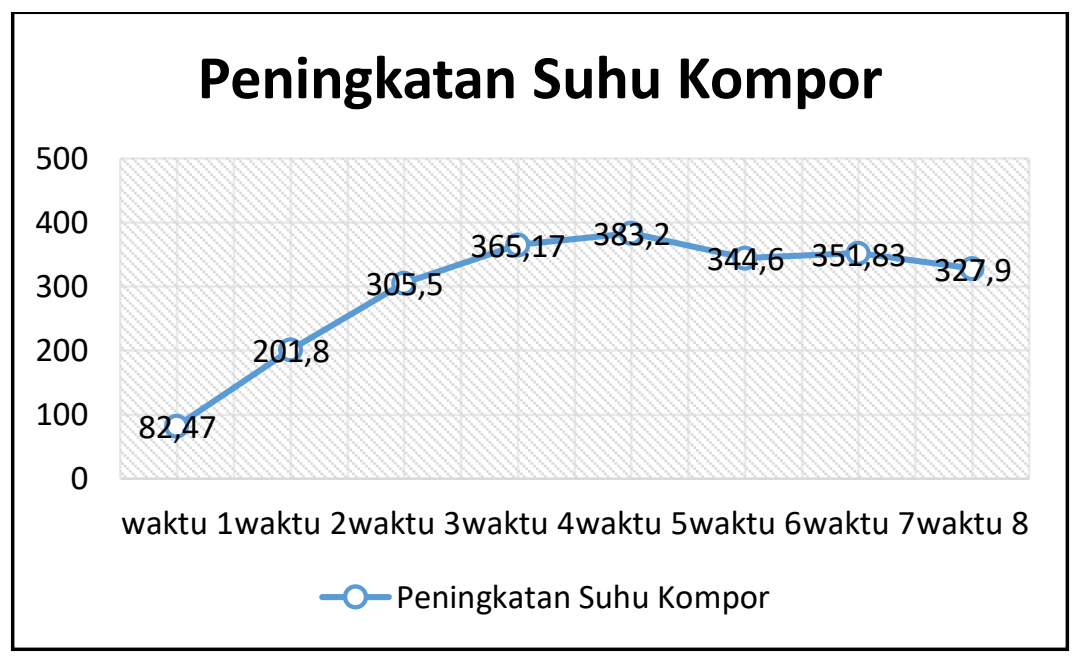

gambar 1. grafik peningkatan suhu kompor

b. Grafik suhu dalam tungku

Suhu dalam tungku juga meningkat seiring peningkatan suhu kompor. Pengukuran suhu dalam tungku menggunakan termometer yang sudah terpasang pada tungku pembakaran.

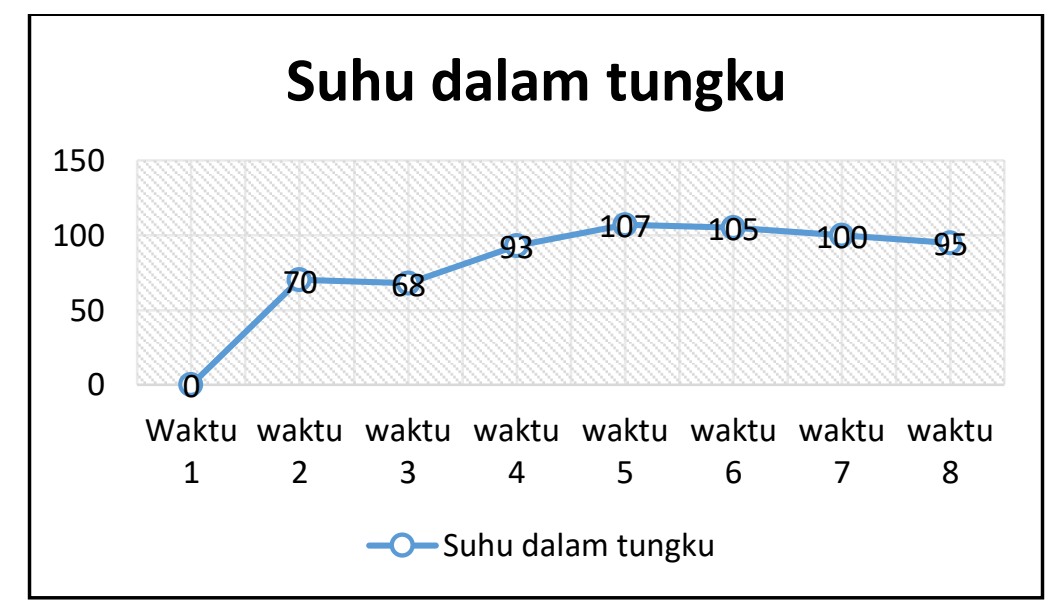

gambar 2. grafik suhu dalam tungku

c. Grafik suhu luar tungku

Suhu luar tingku diambil dari 3 lokasi yang berbeda, secara umum menunjukkan tren yang sama, yaitu semakin meningkat. Hanya saja perbedaan suhu yang menunjukkan perbedaan di tiga lokasi tersebut. 


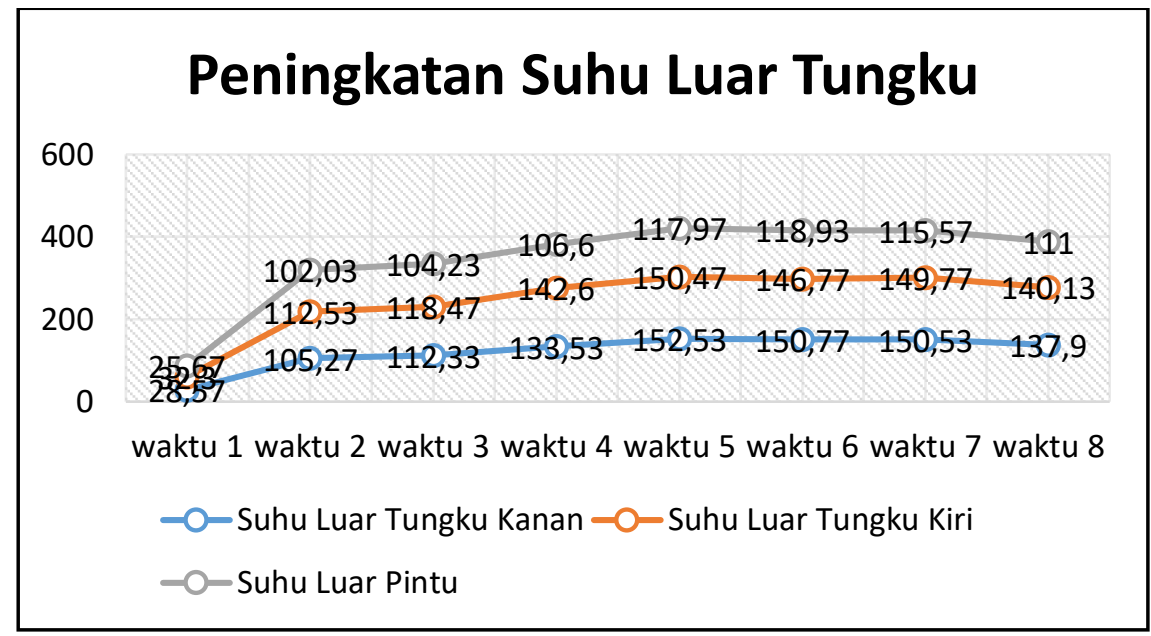

gambar 3. grafik suhu luar tungku

d. Grafik suhu ruang pendingin

Pada ruang pendingin, suhu naik turun tidak teratur. Hal tersebut dikarenakan bahan pendingin menggunakan es batu. Sehingga saat es batu masih banyak, maka suhu bisa sangat dingin. Namun saat es batu sudah mencair, maka suhu mulai meningkat.

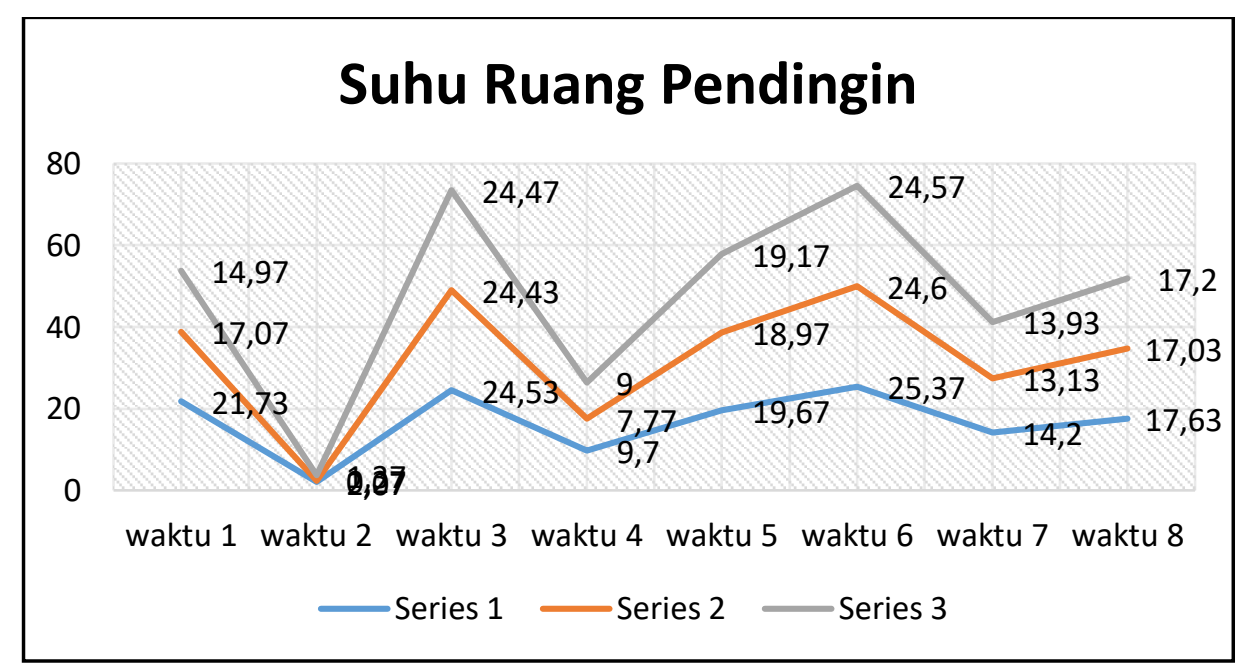

gambar 4. grafik suhu ruang pendingin

e. Grafik penambahan volume cairan

Dari hasil pembakaran, diperoleh hasil yang semakin meningkat. Namun lamakelamaan grafik tersebut menunjukkan penambahan yang semakin sedikit di akhir proses pemasakan. 


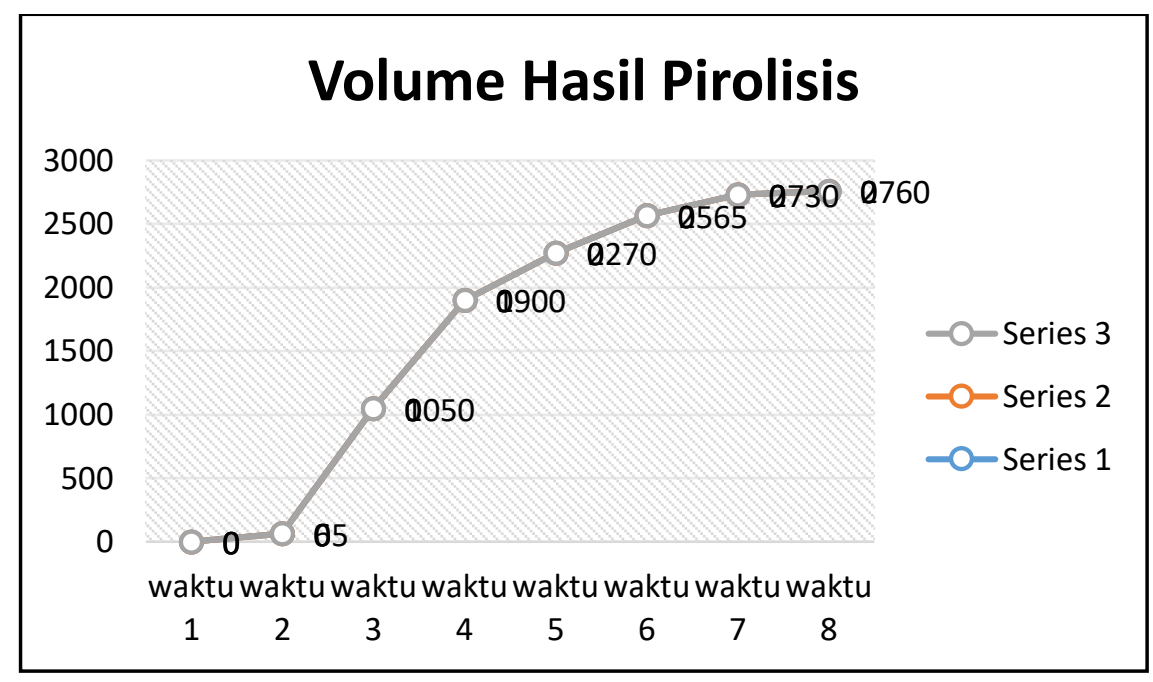

gambar 5. grafik penambahan volume cairan

\section{KESIMPULAN}

Dari penelitian ini, diperoleh beberapa data yang diperoleh dari hasil proses pirolisis tersebut. Dari data yang telah diketahui, untuk suhu api meningkat pada awal pembakaran. Namun setelah mencapai suhu $383,2^{\circ} \mathrm{C}$, suhu cenderung stabil dengan gerakan relatif menurun. Pada suhu luar tungku, menunjukkan tren yang sama, yaitu semakin meningkat sampai pada batas waktu tertentu. Sedangkan pada suhu dalam tungku, juga meningkat seiring peningkatan suhu kompor sampai pada batas waktu tertentu, dan jumlah BBM hasil pirolisis cenderung meningkat, sampai pada suatu waktu cenderung stabil. Hal itu menandakan bahwa proses telah selesai karena sampah sudah tidak bisa diolah menjadi bahan bakar cair lagi. Sedangkan untuk suhu ruang pendingin, terjadi kenaikan dan penurunan yang tidak stabil. Sehingga tidak bisa digambarkan dengan baik.

\section{DAFTAR PUSTAKA}

[1] M. Aris dan M. Sudiaman, "Setiap Hari Indonesia Produksi Sampah 65 Juta Ton," Republika.co.id, 2017. [Online]. Available: https://nasional.republika.co.id/berita/nasional/daerah/17/03/15/omv2sg319setiap-hari-indonesia-produksi-sampah-65-juta-ton. [Accessed: 24-Dec2018].

[2] KLH, Buku Panduan Mengelola Sampah Rumah Tangga Dengan Prinsip 4R (Reduce, Reuse, Recycle, Replant). Riau: Kementrian Lingkungan Hidup RI, 2007. 
[3] VEDC Malang, Sampah dan Pengelolaannya. Malang: Indah Offset, 1998.

[4] Anonim, "Waktu Pembusukan Sampah," http://www.erabaru.net, 2016. [Online]. Available: http://www.erabaru.net/2016/05/26/tahukah-andaberapa-lama-sampah-anda-membusuk/. [Accessed: 11-Oct-2018].

[5] S. Subekti, "Pengelolaan Sampah Rumah Tangga 3R Berbasis Masyarakat," in Prosiding Seminar Nasional Sains Dan Teknologi Fakultas Teknik Universitas Wahid Hasyim Semarang, 2010, pp. 24-30. 